\title{
Geochemical Data for Illinois Basin Coal Samples, 2015-2018
}

Data Series 1135 



\section{Geochemical Data for Illinois Basin Coal Samples, 2015-2018}

By Allan Kolker, Clint Scott, Liliana Lefticariu, Maria Mastalerz, Agnieszka

Drobniak, and Annie Scott

Data Series 1135 


\section{U.S. Geological Survey, Reston, Virginia: 2021}

For more information on the USGS - the Federal source for science about the Earth, its natural and living resources, natural hazards, and the environment-visit https://www.usgs.gov or call 1-888-ASK-USGS.

For an overview of USGS information products, including maps, imagery, and publications, visit https://store.usgs.gov/.

Any use of trade, firm, or product names is for descriptive purposes only and does not imply endorsement by the U.S. Government.

Although this information product, for the most part, is in the public domain, it also may contain copyrighted materials as noted in the text. Permission to reproduce copyrighted items must be secured from the copyright owner.

Suggested citation:

Kolker, A., Scott, C., Lefticariu, L., Mastalerz, M., Drobniak, A., and Scott, A., 2021, Geochemical data for Illinois Basin coal samples, 2015-2018: U.S. Geological Survey Data Series 1135, 14 p., https://doi.org/10.3133/ds1135.

Associated data for this publication:

Kolker, A., Scott, C.T., Croke, M.R., Lefticariu, L., Mastalerz, M., Drobniak, A., and Scott, A.M., 2021, Geochemical data for Illinois Basin coal samples, 2015-2018: U.S. Geological Survey data release, https://doi.org/10.5066/ PGGUURCK.

ISSN 2327-638X (online) 


\section{Acknowledgments}

This study was funded by the U.S. Geological Survey (USGS) Energy Resources Program as part of the USGS Geochemistry of Energy Fuels Project. Samples were collected by USGS collaborators at Southern Illinois University under USGS Cooperative Agreement G16AC00449, and the Indiana Geological and Water Survey under USGS Cooperative Agreement G16AC00448. We are grateful to the mine operators for providing access to their mining and preparation operations for sampling. The authors thank USGS reviewers for improving the content and presentation of this report. Alan Koenig of the USGS Geology, Geophysics, and Geochemistry Science Center in Denver is acknowledged for assistance in obtaining laser ablation inductively coupled plasma mass spectrometry (LA-ICP-MS) results and data processing. Javin Hatcherian of the USGS Eastern Energy Resources Science Center (EERSC) is acknowledged for skillful preparation of polished sections used in coal microanalysis. Brett Valentine and Ryan McAleer of the EERSC assisted in operation of the Reston scanning electron microscope (SEM) and microprobe facilities, respectively. José Vigil and Steve Cahan prepared geographic information system (GIS) output of sample locations shown in figure 1. 



\section{Contents}

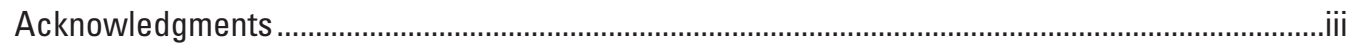

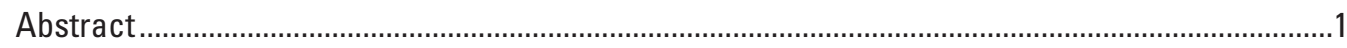

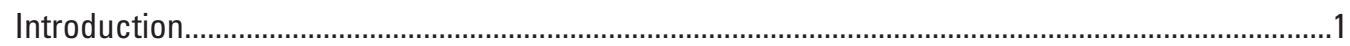

Sample Descriptions and Collection Methods ..........................................................................

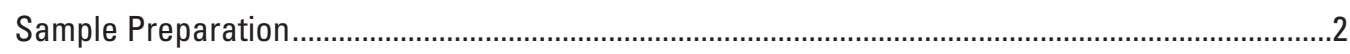

Analytical Methods

Approach

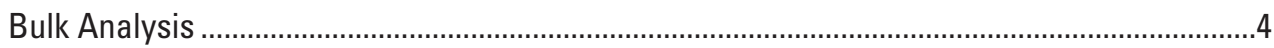

Proximate Analysis, Ultimate Analysis, and Sulfur Forms ...............................................4

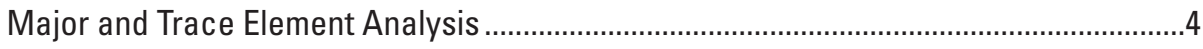

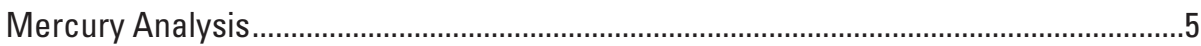

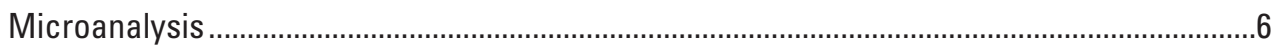

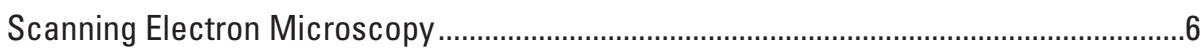

Electron Microprobe Elemental Mapping …………………............................................

Laser Ablation ICP-MS Analysis ...................................................................................

Coal Maceral Analysis ...............................................................................................

References Cited.................................................................................................................

Appendix 1. FE-SEM Images of Pyrite in Illinois Basin Coal Samples...........................................10

\section{Figures}

1. Map showing the distribution of Illinois Basin coal samples collected in Illinois and Indiana...

\section{Tables}

1. Digestion and analysis methods for trace elements in coal and their detection limits

2. Results of mercury determination of coal samples from the Herrin \#6 Coal

Prep Plant.. 


\section{Abbreviations}

Actlabs Activation Laboratories, Ltd.

$\mathrm{Ag} \quad$ silver

As arsenic

ASTM American Society for Testing and Materials (now ASTM International)

Au gold

B boron

$\mathrm{Bi} \quad$ bismuth

C carbon

${ }^{\circ} \mathrm{C} \quad$ degrees Celsius

Cd cadmium

Co cobalt

$\mathrm{Cr} \quad$ chromium

$\mathrm{Cu} \quad$ copper

EERSC USGS Eastern Energy Resources Science Center

EPA U.S. Environmental Protection Agency

EPMA electron probe microanalysis

$\mathrm{Fe} \quad$ iron

FE-SEM field emission scanning electron microscope/microscopy

g grams

H hydrogen

$\mathrm{HCl} \quad$ hydrochloric acid

$\mathrm{Hg} \quad$ mercury

$\mathrm{HgCl}_{2}$ mercury chloride

ICP-AES inductively coupled plasma atomic emission spectroscopy

ICP-MS inductively coupled plasma mass spectrometry

ICP-OES inductively coupled plasma optical emission spectroscopy

ICCP International Committee for Coal and Organic Petrology

IGWS Indiana Geological and Water Survey

INAA instrumental neutron activation analysis

Ir $\quad$ iridium

IR infrared

kV kilovolts

LA-ICP-MS laser ablation inductively coupled plasma mass spectrometry

Li lithium 


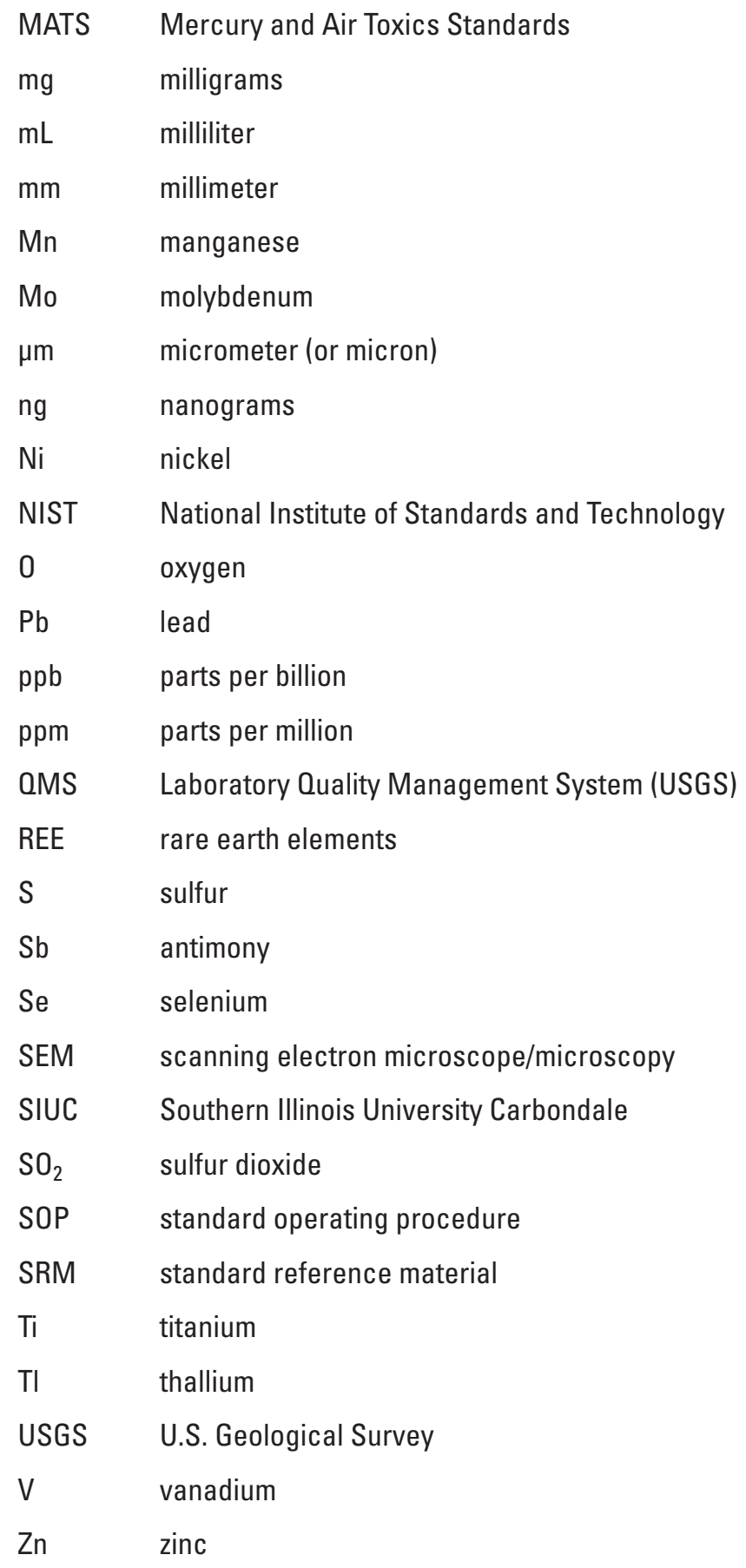





\title{
Geochemical Data for Illinois Basin Coal Samples, 2015-2018
}

\author{
By Allan Kolker, Clint Scott, Liliana Lefticariu, Maria Mastalerz, Agnieszka Drobniak, and Annie Scott
}

\section{Abstract}

Researchers at the U.S. Geological Survey (USGS) and their collaborators conducted a study of the geochemical properties of coals currently produced for electric power generation in the Illinois Basin in Illinois and Indiana. The study follows from recommendations by an expert panel for the USGS to investigate the distribution and controls of trace constituents such as mercury $(\mathrm{Hg})$ in Illinois Basin coals and the behavior of these constituents in coal preparation. A total of 72 new samples were collected by USGS collaborators between 2015 and 2017. These samples include raw coals, prepared coals, and waste coals from coal preparation. To understand the geochemistry and cleaning behavior of these coals, these samples were subjected to an integrated series of analyses described here, including microanalysis of coal constituents and bulk sample chemical analysis. Of the procedures used, wholesample $\mathrm{Hg}$ analysis quantified overall mercury contents and its reduction by coal preparation. Laser ablation inductively coupled plasma mass spectrometry (LA-ICP-MS) of pyrite in coal quantified $\mathrm{Hg}$ and other potentially harmful elements contained in pyrite, the most likely host of these constituents. Trace elements investigated include those whose emissions are regulated under the U.S. Environmental Protection Agency (EPA) Mercury and Air Toxics Standards (MATS; U.S.

Environmental Protection Agency, 2011). This report and the corresponding data release (Kolker and others, 2021), serve as an archive for geochemical data obtained in our study of the geochemistry of Illinois Basin coals. Material included in this report also define approaches used by the USGS over the period of study to characterize coal samples, requiring combined use of results from USGS and non-USGS laboratories.

\section{Introduction}

Near the conclusion of the first U.S. Geological Survey (USGS) Geochemistry of Energy Fuels project (Oct. 1, 2010, to Sept 30,2015), a panel of 25 experts in coal geochemistry was surveyed regarding priorities for new USGS project work on mercury (Hg) in U.S. coals, whose emission had become regulated under the U.S. Environmental Protection
Agency (EPA) Mercury and Air Toxics Standards (MATS) (U.S. Environmental Protection Agency, 2011). The consensus of the panel was that new studies of $\mathrm{Hg}$ in U.S. coals were beneficial to the USGS and the Nation (Kolker, 2016). The panel identified the Illinois Basin as one of the highest priority areas for new studies of $\mathrm{Hg}$ and associated trace elements in coal. This report and the recent accompanying data release (Kolker and others, 2021) are the result of new sampling of Illinois Basin coals in the succeeding second USGS Geochemistry of Energy Fuels project (Oct. 1, 2015, to Sept. 30,2020 ). The goals of this sampling are to better understand the controls on $\mathrm{Hg}$ and trace element distribution in Illinois Basin coals, and the behavior of these elements during coal preparation. These data also serve as a partial update to geochemical results included in the 2002 USGS Illinois Basin coal resource assessment (Hatch and Affolter, 2002). While U.S. coal production has declined in recent years as coal use for power generation has been supplanted by gas-fired capacity, that decline has been least pronounced in the Illinois Basin, as Illinois Basin coals are currently (2018-2019) the most costcompetitive U.S. coal source. The high sulfur content of some Illinois Basin coals is no longer an impediment to their use in power generation as sulfur dioxide scrubbers are increasingly employed in modern coal-fired power stations. For these reasons, the expert panel recommended that among potential new study areas, the USGS investigate controls on Hg and trace element distribution in Illinois Basin coals.

\section{Sample Descriptions and Collection Methods}

A total of 72 new coal, waste coal, and prepared coal samples were obtained from the southern and east-central portions of the Illinois Basin in Illinois, and from the eastern margin of the basin in southwest Indiana (fig. 1). Samples include raw coal, cleaned coal, and waste (refuse) coal samples collected from working operations, from both surface and underground workings (Kolker and others, 2021, tables 1.1 and 1.2). Illinois coals represented in this sampling include the Herrin \#6 (30 samples), Springfield \#5 (5 samples), Colchester \#2 (1 sample), De Koven (4 samples), Davis \#2 
(1 sample), and Murphysboro (2 samples), listed in descending stratigraphic order (Willman and others, 1975). Indiana coals sampled include the Danville \#7 (2 samples), Hymera \#6 (1 sample), Springfield \#5 (6 samples), Bucktown \#5a (1 sample), Buffaloville (4 samples), Upper Block (4 samples) and Lower Block (6 samples), listed in descending stratigraphic order. In addition, five samples from Indiana consist of mixed coals from different stratigraphic horizons. No new samples were obtained from the Kentucky part of the Basin. The 2002 USGS Illinois Basin coal resource assessment emphasized the three most important producing horizons, the Danville-Baker, Herrin, and Springfield coals (Hatch and Affolter, 2002). Coals below the Springfield \#5 were not assessed, and results for these coals were included only as averages by formation, including multiple non-assessed units. In the present study, major and trace element data are provided for the coals listed above, with the exception of the Buffaloville coal in Indiana, which is not an important commercial producer.

\section{Sample Preparation}

Initial sample preparation for whole sample (bulk) analysis and microanalysis was conducted at Geochemical Testing, Inc., of Somerset, Penn., (hereafter, referred to as Geochemical Testing). Samples collected by USGS collaborators at Southern Illinois University Carbondale (SIUC) and the Indiana Geological and Water Survey (IGWS) were returned directly to Geochemical Testing, where raw samples were prepared according to ASTM D2013/D2013M-20 (ASTM International, 2020). Bulk sample splits were ground to pass (95 percent) 60 mesh ( 0.250 millimeters [mm]) for bulk chemical analysis, and ground to pass (95 percent) 20 mesh (0.841 $\mathrm{mm}$ ) for microanalysis. These representative splits were then provided to the USGS, together with archival material used to prepare the splits. Prior to providing prepared sample material to the USGS, Geochemical Testing also conducted proximate, ultimate, and sulfur forms analysis using ASTM methods (Kolker and others, 2021, tables 2.1 and 2.2).

Polished pellets of 20-mesh (petrographic) fractions were prepared in Reston, Va., at the USGS Coal Petrography Lab. Pellets were prepared in duplicate, for elemental microanalysis, and coal maceral analysis, respectively. Polished sections for elemental microanalysis were used in scanning electron microscope (SEM), electron microprobe, and laser-ablation inductively coupled plasma mass spectrometry (LA-ICP-MS) analysis. Duplicate polished pellets were sent to IGWS, in Bloomington, Ind., for coal maceral analysis. Polished sample pellets were prepared according to ASTM D2799-13 (ASTM International, 2013a), in which pellets are prepared from crushed coal cast in a thermoplastic acrylic powder. Samples were ground and polished using an automatic grinder/polisher. The abrasion sequence used was 240 -grit, 400 -grit, 600 -grit, and 1200-grit silicon carbide paper. The polishing sequence used was a 0.3 -micron $(\mu \mathrm{m})$ alumina polish on non-woven, pressed cloth, with a final polish using $0.06-\mu \mathrm{m}$ colloidal silica on synthetic velvet cloth. 


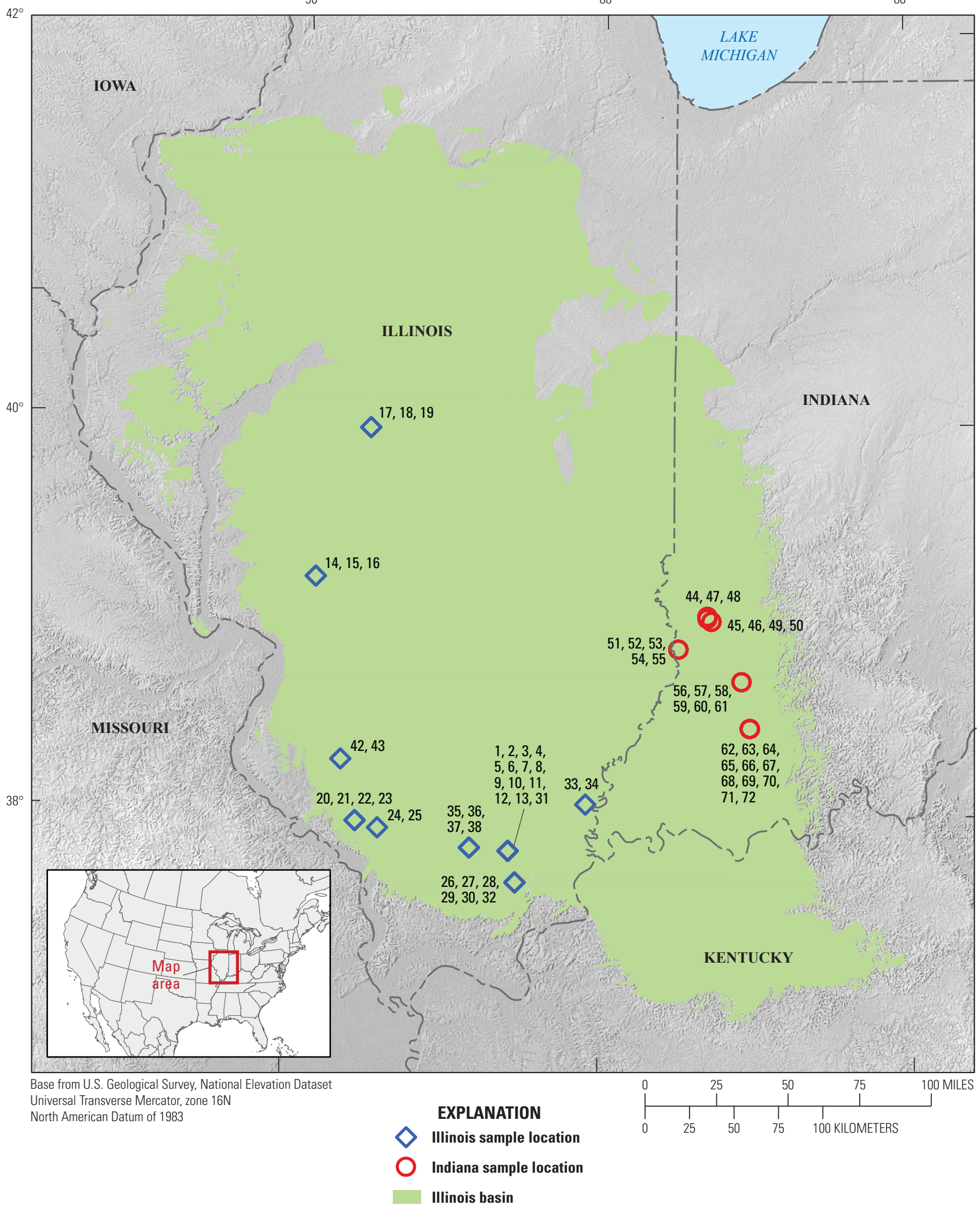

Figure 1. Map showing the distribution of Illinois Basin coal samples collected in Illinois and Indiana. Samples are numbered according to their listing in Kolker and others (2021, tables 1.1 and 1.2). Sample numbers 39, 40, and 41 are not shown as their location is proprietary. 


\section{Analytical Methods}

\section{Approach}

A combination of bulk sample analysis and microanalysis methods were used. These approaches encompass use of both USGS and commercial labs, and for coal maceral determination, a USGS collaborator laboratory. Where applicable, sampling, characterization, and analysis of coal samples followed ASTM methods. Labs operated by the USGS Eastern Energy Resources Science Center (EERSC), now the Geology, Energy and Minerals Science Center, are subject to the Eastern Energy Quality Management System (QMS), implemented on May 1, 2017. These include the Reston Electron Beam Laboratory (electron microprobe, field emission scanning electron microscope), the Reston Coal Petrography Lab, and the Reston Trace Element Instrument Laboratory (mercury analyzer). These laboratories follow QMS-approved standard operating procedures (SOPs). Other USGS laboratories, including the Denver laser ablation ICP-MS laboratory, follow independent quality assurance procedures in advance of USGS Bureauwide QMS implementation.

\section{Bulk Analysis}

\section{Proximate Analysis, Ultimate Analysis, and Sulfur Forms}

Using ASTM methods, a series of tests giving information on overall coal quality for each sample was provided to the USGS by Geochemical Testing. Proximate analysis (ASTM D3172-13; ASTM International, 2013b) encompasses the determination of moisture, volatile matter, ash yield, and the calculation of fixed carbon by difference, each having specific ASTM methods. Moisture (ASTM D3302/ D3302M-17; ASTM International, 2017) and ash-yield (ASTM D3174-12(2018); ASTM International, 2018a) are determined by mass balance following drying and combustion, respectively, of a sample of coal having a known mass. Ultimate analysis (ASTM D3176-15; ASTM International, 2015) is a bulk chemical assay, and includes determination of hydrogen $(\mathrm{H})$, carbon $(\mathrm{C})$, nitrogen $(\mathrm{N})$, oxygen $(\mathrm{O})$, and total sulfur (S), together with ash yield from proximate analysis (Kolker and others, 2021, tables 2.1 and 2.2). Total S (ASTM D4239-18e1; ASTM International, 2018b) is measured as $\mathrm{SO}_{2}$ (grams [g]) using infrared (IR) spectrometry following combustion. Heating value (ASTM D5865-13; ASTM International, 2013c), determined as part of coal characterization, is measured using a calibrated calorimeter. Forms of sulfur (ASTM D2492-02(2012); ASTM International, 2012) include sulfate, sulfide, and organic forms. Sulfate S is determined gravimetrically following extraction via dilute hydrochloric acid $(\mathrm{HCl})$. Sulfide $\mathrm{S}$ is assumed to be dominantly pyritic (pyritic sulfur) and is therefore calculated as a stoichiometric combination with iron $(\mathrm{Fe})$. Organic sulfur is a calculated parameter, determined by subtraction of sulfate and sulfide from the total sulfur measured above. Pyritic sulfur is especially useful as a measure of the proportion of total sulfur in coal occurring as pyrite.

\section{Major and Trace Element Analysis}

Major and trace element data were determined by Activation Laboratories, Ltd. (Actlabs), Ancaster, Ontario, Canada using a dedicated coal analysis package that includes element determination by inductively coupled plasma atomic emission spectroscopy (ICP-AES) and (or) inductively coupled plasma optical emission spectroscopy (ICP-OES; hereafter, referred to as ICP), as well as inductively coupled plasma mass spectrometry (ICP-MS), and instrumental neutron activation (INAA; table 1; Kolker and others, 2021, tables 3.1, 3.2, and 3.3). Prior to analysis, 60-mesh splits of bulk samples were combusted by Actlabs at $525^{\circ} \mathrm{C}$ for 36 hours to produce laboratory ash used in ICP and ICP-MS determinations. Compared to the ASTM D3174-12(2018) (ASTM International, 2018a) ash yield determination at $750^{\circ} \mathrm{C}$, coal combustion at $525^{\circ} \mathrm{C}$ is thought to limit loss of moderately volatile trace elements such as arsenic (As), and antimony ( $\mathrm{Sb}$ ), while retaining all but the most volatile elements such as mercury $(\mathrm{Hg})$ and selenium $(\mathrm{Se})$. This approach to preparation of laboratory ash for analysis was followed in past elemental analysis of coal by the USGS (Golightly and Simon, 1989; Palmer, 1997).

After laboratory combustion at $525^{\circ} \mathrm{C}$, the resulting ash was digested using a lithium metaborate/tetraborate fusion and brought into solution for ICP and ICP-MS analysis. Major elements were determined by ICP following fusion digestion. The detection limit for individual major element oxides by ICP is 0.01 percent, except for $\mathrm{MnO}$ and $\mathrm{TiO}_{2}$, for which the detection limit is 0.001 percent. For elements primarily associated with metals $(\mathrm{Ni}, \mathrm{Cu}, \mathrm{Zn}, \mathrm{Pb}, \mathrm{S})$, a multi-acid digestion (including nitric, perchloric, hydrofluoric and hydrochloric acids), was used prior to determination by ICP. To ensure that elements with potential for volatilization are quantified, such as $\mathrm{Se}$ and $\mathrm{Sb}$, these were determined on aliquots of whole coal, by INAA (table 1).

For trace elements, detection limits by ICP, ICP-MS, and INAA range from 5 parts per million (ppm) for $\mathrm{V}, \mathrm{Cr}, \mathrm{Pb}$, to the parts per billion (ppb) range for Ir and Au by INAA (table 1). Most trace elements determined by these combined techniques with contents in the ppm have detection limits in the 0.1 to $1.0 \mathrm{ppm}$ range (table 1 ). Results determined by ICP and ICP-MS on coal ash reported in Kolker and others (2021) are converted to a whole-coal basis using values obtained for moisture and ash yield immediately prior to analysis. As an internal check for decomposition of rare earth element (REE)bearing trace phases such as zircon and monazite, chondritenormalized plots of sample REE contents were included with quality assurance documentation provided by the laboratory. 
Table 1. Digestion and analysis methods for trace elements in coal and their detection limits.

[Source: Activation Laboratories Ltd. (Actlabs) (2020), at https://actlabs.com/. ICP, inductively coupled plasma; ICP-MS, inductively coupled plasma mass spectrometry; INAA, instrumental neutron activation analysis; ppb, parts per billion; ppm, parts per million]

\begin{tabular}{lccc}
\hline \multicolumn{1}{c}{ Element(s) } & Digestion & Analysis & Detection limit, in ppm \\
\hline $\mathrm{V}$ & Fusion & ICP & 5 \\
$\mathrm{~Pb}$ & Acid & ICP & 5 \\
$\mathrm{Cr}$ & None & INAA & 5 \\
$\mathrm{Se}$ & None & INAA & 3 \\
$\mathrm{Sr}, \mathrm{Zr}, \mathrm{Ba}$ & Fusion & ICP & 2 \\
$\mathrm{Rb}, \mathrm{Mo}$ & Fusion & ICP-MS & 2 \\
$\mathrm{Be}, \mathrm{Y}$ & Fusion & ICP & 1 \\
$\mathrm{Co}, \mathrm{Ga}, \mathrm{Ge}, \mathrm{Nb}, \mathrm{Sn}, \mathrm{W}$ & Fusion & 1 \\
$\mathrm{Ni}, \mathrm{Cu}, \mathrm{Zn}$ & Acid & ICP-MS & 1 \\
$\mathrm{Ag}, \mathrm{Cs}$ & Fusion & ICP & 0.5 \\
$\mathrm{Cd}$ & Acid & ICP-MS & 0.5 \\
$\mathrm{As}, \mathrm{Br}$ & None & ICP & 0.5 \\
$\mathrm{Bi}$ & Fusion & INAA & 0.4 \\
$\mathrm{In}, \mathrm{Hf}$ & Fusion & ICP-MS & 0.2 \\
$\mathrm{Sb}$ & None & ICP-MS & 0.2 \\
$\mathrm{La}, \mathrm{Ce}, \mathrm{Nd}, \mathrm{Sm}, \mathrm{Gd}, \mathrm{Tb}, \mathrm{Dy}, \mathrm{Ho}, \mathrm{Er}, \mathrm{Yb}, \mathrm{Ta}, \mathrm{Tl}, \mathrm{Th}, \mathrm{U}$ & INAA & 0.1 \\
$\mathrm{Sc}$ & Fusion & ICP-MS & 0.1 \\
$\mathrm{Pr}, \mathrm{Eu}, \mathrm{Tm}$ & None & INAA & 0.05 \\
$\mathrm{Lu}$ & Fusion & ICP-MS & 0.01 \\
$\mathrm{Ir}$ & Fusion & ICP-MS & $5 \mathrm{ppb}$ \\
$\mathrm{Au}$ & None & INAA & $2 \mathrm{ppb}$ \\
\hline
\end{tabular}

In addition to the procedure described above, for a subset of 13 ashed coal samples (IL-1 to IL-8, and SIUC-2 to SIUC-6) a sodium peroxide fusion digestion approach was used (Kolker and others, 2021, table 3.1) prior to determination by ICP and ICP-MS. Like the lithium metaborate/ tetraborate fusion procedure, sodium peroxide fusion is superior to acid digestion for decomposition of insoluble trace phases that carry REEs (Kolker, 2018). Detection limits obtained by ICP and ICP-MS following sodium peroxide fusion, are comparable to those obtained in the procedure using lithium metaborate/tetraborate fusion. However, with addition of sodium peroxide, sodium cannot be determined as a major oxide. And without separate determination on whole coal by INAA, Se is assumed to be all or partially lost in the ashing process. Preparation of ash at $525^{\circ} \mathrm{C}$ minimizes loss of other, moderately volatile trace elements such as $\mathrm{Sb}$, which were determined by INAA on whole coal (together with $\mathrm{Se}$ ) in the procedure used for all samples except for samples IL-1 to IL-8 and samples SIUC-2 to SIUC-6. Use of lithium metaborate/tetraborate fusion for the larger group of samples does not allow determination of lithium (Li) and boron (B), which cannot be measured following addition of lithium metaborate/tetraborate.

\section{Mercury Analysis}

Mercury $(\mathrm{Hg})$ contents for Illinois Basin coal samples were determined at the USGS EERSC in Reston, Va., using a Nippon MA-3000 instrument (Kolker and others, 2021, tables 4.1 and 4.2). This and similar benchtop Hg analyzers utilize EPA Method 7473, in which samples are heated and the evolved $\mathrm{Hg}$ is selectively captured as an amalgam and measured by atomic absorption spectrophotometry (U.S. Environmental Protection Agency, 2007). Mercury results were acquired under the USGS Eastern Energy QMS, according to a QMS-approved standard operating procedure (SOP) (Scott and Kolker, 2018). The SOP broadly follows operating procedures outlined in the Nippon MA-3000 instrument manual. The MA-3000 has an absolute detection limit of 0.002 nanograms (ng) $\mathrm{Hg}$, a linear range from 0.002 to $2000 \mathrm{ng} \mathrm{Hg}$, and an upper, non-linear range of 25,000 $\mathrm{ng} \mathrm{Hg}$. Two calibration ranges (low, 0-10 ng; high, 20-200 ng) are used. The instrument features automatic switching between low and high dynamic ranges as needed. A typical working range for the method is 0.05 to $600 \mathrm{ng} \mathrm{Hg}$. For a routine sample loading of 50 milligrams $(\mathrm{mg})$, this corresponds to a 
nominal detection limit of $1 \mathrm{ppb} \mathrm{Hg}$. All samples that were determined fall within the range of the primary calibration standards and the linear range for the instrument.

Quantification is achieved using a series of calibration standards prepared from mercury chloride $\left(\mathrm{HgCl}_{2}\right)$ stock solution having a concentration of $1.0 \mathrm{mg} \mathrm{Hg} / \mathrm{mL}$. A calibration curve is obtained by running primary calibration standards prepared by diluting a $\mathrm{HgCl}_{2}$ stock solution with an L-cysteine preservative solution to contain $0.0,0.5,1.0,5.0,10.0,20.0$, 50.0, 100, and $200 \mathrm{ng} \mathrm{Hg}$. NIST standard reference materials (SRMs) including NIST 1632d (Trace Elements in Coal (bituminous) NIST, 2014) and NIST 1633c (Trace Elements in Coal Fly Ash, NIST, 2011) are used as internal standard reference materials. In a typical sample analysis sequence, following initial instrument calibration, two SRMs and a blank are run before and after each series of 10 unknowns (Scott and Kolker, 2018). Results obtained prior to- and following implementation of the QMS are highly comparable (table 2).

\section{Microanalysis}

\section{Scanning Electron Mcroscopy}

All microanalyses (from SEM, electron microprobe (EPMA), and LA-ICP-MS) were conducted on the same set of polished pellets as described above. For scanning electron microscopy, all samples included in the study were analyzed using a Hitachi SU5000 variable pressure field-emission scanning electron microscope (FE-SEM) at the USGS Reston Electron Beam Laboratory. The FE-SEM was used in both the SEM and backscattered modes to identify potential hosts of elements of environmental interest in coal, such as pyrite (Kolker, 2012). Backscattered electron imaging is especially useful in identifying non-silicate minerals such as pyrite, as well as trace metal zoning within pyrite, due to their contrast in mean atomic number compared to carbonaceous or aluminosilicate hosts. Operating procedures for the Hitachi SU5000 FE-SEM are given in the QMS-approved laboratory SOP (Valentine, 2018). In the present study, the instrument was operated at 15 kilovolts $(\mathrm{kV})$, an instrument-specific unitless spot size of 30 (range 1 to 100), and a working distance of $10 \mathrm{~mm}$.

\section{Electron Microprobe Elemental Mapping}

Representative pyrite grains identified in the coal samples identified by the FE-SEM were checked for minor element compositional variation by backscattered electron imaging and wavelength-dispersive elemental mapping, using the JEOL JXA 8900R electron microprobe at the USGS Reston Electron Beam Laboratory. The operating conditions for elemental mapping were $20-\mathrm{kV}$ accelerating voltage and 300 nanoamps (nA) of beam current. Pixel dwell time for all maps was 30 milliseconds per pixel, whereas step size (that is pixel size) varied between 0.5 and $2 \mu \mathrm{m}$ depending on the map, with most maps collected with a $1-\mu \mathrm{m}$ step size; map dimensions were adjusted according to the size of the region of interest. Raw intensity maps were acquired in two analytical sessions. In the first session $\mathrm{Fe}, \mathrm{S}, \mathrm{Cu}, \mathrm{Zn}$, and $\mathrm{As}$ were analyzed and in the second session Se was analyzed instead of Zn. For both sessions the analyzing crystals and X-ray lines were: spectrometer 1, Fe K-alpha (lithium fluoride [LIF] analyzing crystal); spectrometer 2, Cu K-alpha (LIFH analyzing crystal; also lithium fluoride, but curved to fit an H-type spectrometer with a Rowland circle of $100 \mathrm{~mm}$ ); spectrometer 3, As La-alpha (thallium acid phthalate [TAP] analyzing crystal). For session 1, additional analyzing crystals were: spectrometer 4, Zn K-alpha (LIF analyzing crystal); and spectrometer 5, $\mathrm{S}$ K-alpha (PET analyzing crystal). For session 2, additional analyzing crystals were: spectrometer 4, S K-alpha (pentaerythritol [PET] analyzing crystal); and spectrometer 5, Se L-alpha (TAP analyzing crystal). Mapping at these conditions

Table 2. Results of mercury determination of coal samples from the Herrin \#6 Coal Prep Plant.

[Results are from the U.S. Geological Survey, Eastern Energy Resources Science Center (EERSC) in Reston, Va., using a Nippon MA-3000 instrument. ${ }^{1}$ Results obtained prior to May 1, 2017, are for informational purposes only. ${ }^{2}$ Mixed product includes IL-2, IL-4, and IL-6 clean coal samples. Hg, mercury; ppb, parts per billion (on an as-received basis)]

\begin{tabular}{llccc}
\hline Sample number & \multicolumn{1}{c}{ Material } & $\begin{array}{c}\text { Hg, in ppb, } \\
\text { analyst A, } \\
\text { April 10, 2018 }\end{array}$ & $\begin{array}{c}\text { Hg, in ppb, } \\
\text { analyst B, } \\
\text { June 25, 20151 }\end{array}$ & Percent deviation \\
\hline IL-1 & Raw prep plant feed & 228.6 & 236.1 & -3.2 \\
IL-2 & Coarse clean & 105.2 & 102.3 & +2.8 \\
IL-3 & Coarse refuse & 295.4 & 296.7 & -0.4 \\
IL-4 & Intermediate clean & 78.8 & 78.6 & +0.3 \\
IL-5 & Intermediate refuse & 168.0 & 169.0 & -0.6 \\
IL-6 & Fine clean & 73.1 & 71.2 & +2.7 \\
IL-7 & Fine refuse & 129.8 & 133.7 & -2.9 \\
IL-8 & Final mixed product 2 & 84.7 & 86.3 & -1.9 \\
\hline
\end{tabular}


revealed little or no discernable minor element variation in Illinois Basin pyrite, suggesting that concentrations of each minor element mapped were below the electron microprobe detection limit of approximately $100 \mathrm{ppm}$. As nearly all map images of pyrite only show counts for iron and sulfur, these are omitted from this publication.

\section{Laser Ablation ICP-MS Analysis}

Pyrite grains observed in FE-SEM, such as those shown in appendix 1, were analyzed by laser ablation ICP-MS (LAICP-MS) spot analysis at the USGS Geology, Geophysics and Geochemistry Science Center in Denver, Colorado. A greater range of elements was determined by LA-ICP-MS than by electron microprobe mapping, including $\mathrm{V}, \mathrm{Cr}, \mathrm{Mn}$, $\mathrm{Co}, \mathrm{Ni}, \mathrm{Cu}, \mathrm{Zn}, \mathrm{As}$, Se, Mo, Ag, Cd, Sb, Au, Hg, Tl, Pb, and Bi (Kolker and others, 2021, table 5.1). Pyrites were ablated using spot sizes of $25 \mu \mathrm{m}$ or $18 \mu \mathrm{m}$ as necessary, based on the size of targeted grains. Instrument detection limits were obtained daily for each element determined, defined as three times the standard deviation of the blank (instrument response with the laser turned off), and converted to a concentration using the external calibration reference material. Detection limits in the sub-ppm to single ppm range were obtained for elements of interest such as $\mathrm{V}, \mathrm{Co}, \mathrm{As}, \mathrm{Sb}, \mathrm{Hg}, \mathrm{Tl}$, and $\mathrm{Pb}$. Detection limits are generally lower for results determined at $25 \mu \mathrm{m}$ than at $18 \mu \mathrm{m}$ because a larger volume of material is ablated. Calibration uses USGS synthetic sulfide reference material MASS-1, which is homogeneous at a minimum of $20 \mu \mathrm{m}$ (Wilson and others, 2002). In addition, as an internal standard, Fe in pyrite was fixed at its stoichiometric proportion (47 weight percent) and used to correct for yield variation from spot to spot. Response for ${ }^{12} \mathrm{C}$ was monitored during the runs as a qualitative measure of the relative contribution by the organic host during the analysis. This was not quantifiable due to the absence of carbon in the MASS-1 external calibration reference material. Results confirm that trace elements most commonly enriched in pyrite, such as arsenic, are generally present at concentrations below electron microprobe detection limits, and that mercury is commonly present in pyrite at ppm levels, demonstrating its enrichment in pyrite relative to values obtained for Illinois Basin whole coals.

\section{Coal Maceral Analysis}

Maceral analysis of coal was carried out at the Indiana Geological and Water Survey, Indiana University in Bloomington, Ind. The analysis utilized polished pellets prepared at the USGS coal petrography lab in Reston, Va., as described in the section "Sample Preparation." A reflected light microscope Leica DFC310 FX with an oil immersion objective of 50x was used to identify macerals in reflected and fluorescent light. A standard point-counting technique was used with 500 points counted on all samples; the counts were then recalculated into volume percentages. Maceral identification followed established International Committee for Coal and Organic Petrology (ICCP) System 1994 methods (International Committee for Coal and Organic Petrology, 1998, 2001; Pickel and others, 2017). Data and results presented in Kolker and others (2021, tables 6.1 and 6.2), include coal maceral content, mineral matter (MM), and vitrinite reflectance $\left(R_{0}\right)$, in percent. Maceral groups include vitrinite, liptinite, and inertinite.

\section{References Cited}

Activation Laboratories Ltd. (Actlabs), 2020, Coal analysis package: p. 20, accessed May 8, 2020, at https://cdn.actlabs.com/wp-content/uploads/2020/01/ Actlabs-Schedule-of-Services-International.pdf.

ASTM International, 2012, ASTM standard D2492-02(2012), Standard test method for forms of sulfur in coal: West Conshohocken, Penn., ASTM International, v. 05.06, 5 p., accessed May 30, 2019, at https://doi.org/10.1520/D249202R12.

ASTM International, 2013a, ASTM standard D2799-13, Standard test method for microscopical determination of the maceral composition of coal: Annual Book of ASTM Standards, West Conshohocken, Penn., ASTM International, v. 05.06, 6 p., accessed June 5, 2019, at https://doi.org/ $10.1520 / \mathrm{D} 2799-13$.

ASTM International, 2013b, ASTM standard D3172-13, Standard practice for proximate analysis of coal and coke: Annual Book of ASTM Standards, West Conshohocken, Penn., ASTM International, v. 05.06, 2 p., accessed June 3, 2019, at https://doi.org/10.1520/D3172-13.

ASTM International, 2013c, ASTM standard D5865-13, Standard test method for gross calorific value of coal and coke: West Conshohocken, Penn., ASTM International, v. 05.06, 19 p., accessed May 24, 2019, at https://doi.org/ 10.1520/D5865-13.

ASTM International, 2015, ASTM standard D3176-15, Standard practice for ultimate analysis of coal and coke: Annual Book of ASTM Standards, West Conshohocken, Penn., ASTM International, v. 05.06, 4 p., accessed June 4, 2019, at https://doi.org/10.1520/D3176-15.

ASTM International, 2017, ASTM standard D3302/ D3302M-17, Standard test method for total moisture in coal: Annual Book of ASTM Standards, West Conshohocken, Penn., ASTM International, v. 05.06, 10 p., accessed May 24, 2019, at https://doi.org/10.1520/ D3302 D3302M-17. 
ASTM International, 2018a, ASTM standard D3174-12(2018), Standard test method for ash in the analysis sample of coal and coke from coal: Annual Book of ASTM Standards, West Conshohocken, Penn., ASTM International, v. 05.06, 6 p., accessed June 5, 2019, at https://doi.org/10.1520/ D3174-12R18.

ASTM International, 2018b, ASTM standard D4239-18e1, Standard test method for sulfur in the analysis sample of coal and coke using high-temperature tube furnace combustion: Annual Book of ASTM Standards, West Conshohocken, Penn., ASTM International, v. 05.06, 8 p., accessed May 24, 2019, at https://doi.org/10.1520/D4239$18 \mathrm{E} 01$.

ASTM International, 2020, ASTM standard D2013/ D2013M-20, Standard practice for preparing coal samples for analysis: West Conshohocken, Penn., ASTM International, v. 05.06, 12 p., accessed May 23, 2019, at https://doi.org/10.1520/D2013_D2013M-20.

Golightly, D.W., and Simon, F.O., 1989, Methods for sampling and inorganic analysis of coal: U.S. Geological Survey Bulletin 1823, p. 1-5 [72 p.]. [Also available at https://pubs.usgs.gov/bul/1823/report.pdf.]

Hatch, J.R., and Affolter, R.H., 2002, Resource assessment of the Springfield, Herrin, Danville, and Baker coals in the Illinois Basin: U.S. Geological Survey Professional Paper 1625-D, 2 CD-ROMs. [Also available at https://pubs.er.usgs.gov/publication/pp1625D.]

International Committee for Coal and Organic Petrology, 1998, The new vitrinite classification (ICCP System 1994): Fuel, v. 77, no. 5, p. 349-358. [Also available at https://doi.org/10.1016/S0016-2361(98)80024-0.]

International Committee for Coal and Organic Petrology, 2001, The new inertinite classification (ICCP System 1994): Fuel, v. 80, no. 4, p. 459-471. [Also available at https://doi.org/10.1016/S0016-2361(00)00102-2.]

Kolker, A., 2012, Minor element distribution in iron-disulfides in coal-A geochemical review: International Journal of Coal Geology, v. 94, p. 32-43. [Also available at https://doi.org/10.1016/j.coal.2011.10.011.]

Kolker, A., 2016, Mercury in U.S. coal-Priorities for new U.S. Geological Survey studies: U.S. Geological Survey Open-File Report 2016-1033, 21 p. [Also available at https://doi.org/10.3133/ofr20161033.]

Kolker, A., 2018, Topics in coal geochemistry-Short course: U.S. Geological Survey Open File Report 2018-1145, 31 p. [Also available at https://doi.org/10.3133/ofr20181145.]
Kolker, A., Scott, C.T., Croke, M.R., Lefticariu, L., Mastalerz, M., Drobniak, A., and Scott, A.M., 2021, Geochemical data for Illinois Basin coal samples, 2015-2018: U.S. Geological Survey data release, https://doi.org/10.5066/P9GUURCK.

National Institute of Standards and Technology (NIST), 2011, Certificate of analysis standard reference material 1633cTrace elements in coal fly ash: Gaithersburg, Md., National Institute of Standards and Technology, 8 p., accessed May 23, 2019, at https://www-s.nist.gov/srmors/view_cert.cfm? $\mathrm{srm}=1633 \mathrm{C}$.

National Institute of Standards and Technology (NIST), 2014, Certificate of analysis standard reference material 1632d-Trace elements in coal (bituminous): Gaithersburg, Md., National Institute of Standards and Technology, 7 p., accessed May 23, 2019, at https:/www-s.nist.gov/srmors/ view_cert.cfm?srm=1632D.

Palmer, C.A., ed., 1997, The chemical analysis of Argonne Premium Coal samples: U.S. Geological Survey Bulletin 2144, 106 p. [Also available at https://pubs.er.usgs.gov/ publication/b2144.]

Pickel, W., Kus, J., Flores, D., Kalaitzidiz, S., Christanis, K., Cardott, B.J., Misz-Kennan, M., Rodrigues, S., Hentschel, A., Hamor-Vido, M., Crosdale, P., Wagner, N., and ICCP, 2017, Classification of liptinite-ICCP system 1994: International Journal of Coal Geology, v. 169, p. 40-61. [Also available at https://doi.org/10.1016/ j.coal.2016.11.004.]

Scott, A.M., and Kolker, A., 2018, Determination of mercury in energy fuels: U.S. Geological Survey Internal Technical Report, U.S. Geological Survey Energy Resources Program, Quality Management System, Technical Standard Operating Procedure ERP-TEIL-SOP-01.02, 21 p.

U.S. Environmental Protection Agency, 2007, Method 7473Mercury in solids and solutions by thermal decomposition, amalgamation, and atomic absorption spectrophotometry: U.S. Environmental Protection Agency report, 17 p., accessed May 19, 2020, at https://www.epa.gov/sites/ production/files/2015-12/documents/7473.pdf.

U.S. Environmental Protection Agency, 2011, Mercury and air toxics standards (MATS): U.S. Environmental Protection Agency web page, accessed May 19, 2020, at https://www.epa.gov/mats.

Valentine, B., 2018, Field emission scanning electron microscopy (FE-SEM) procedures: U.S. Geological Survey Internal Technical Report, U.S. Geological Survey Energy Resources Program, Quality Management System, Technical Standard Operating Procedure SOP ERPREBSEM-SOP-02.03, $21 \mathrm{p}$. 
Willman, H.B., Atherton, E., Buschbach, T.C., Collinson, C.W., Frye, J.C., Hopkins, M.E., Lineback, J.A., and Simon, J.A., 1975, Handbook of Illinois stratigraphy: Illinois State Geological Survey Bulletin 95, 261 p. [Also available at http://hdl.handle.net/2142/35115.]
Wilson, S.A., Ridley, W.I., and Koenig, A.E., 2002, Development of sulfide calibration standards for the laser ablation inductively-coupled plasma mass spectrometry technique: Journal of Analytical Atomic Spectrometry, v. 17, p. 406-409. [Also available at https://doi.org/10.1039/ b108787h.] 


\section{Appendix 1. FE-SEM Images of Pyrite in Illinois Basin Coal Samples}

Appendix 1 contains backscattered electron (BSE, and [or] BSE-ALL) images (figs. 1.1, 1.2, 1.3, 1.4, 1.6, 1.7, 1.8, and 1.9) and a secondary electron (SE, and [or] SE[L]) image (fig. 1.5) of pyrite $\left(\mathrm{FeS}_{2}\right)$ in Illinois Basin coal samples that were obtained by field emission scanning electron microscopy (FE-SEM).

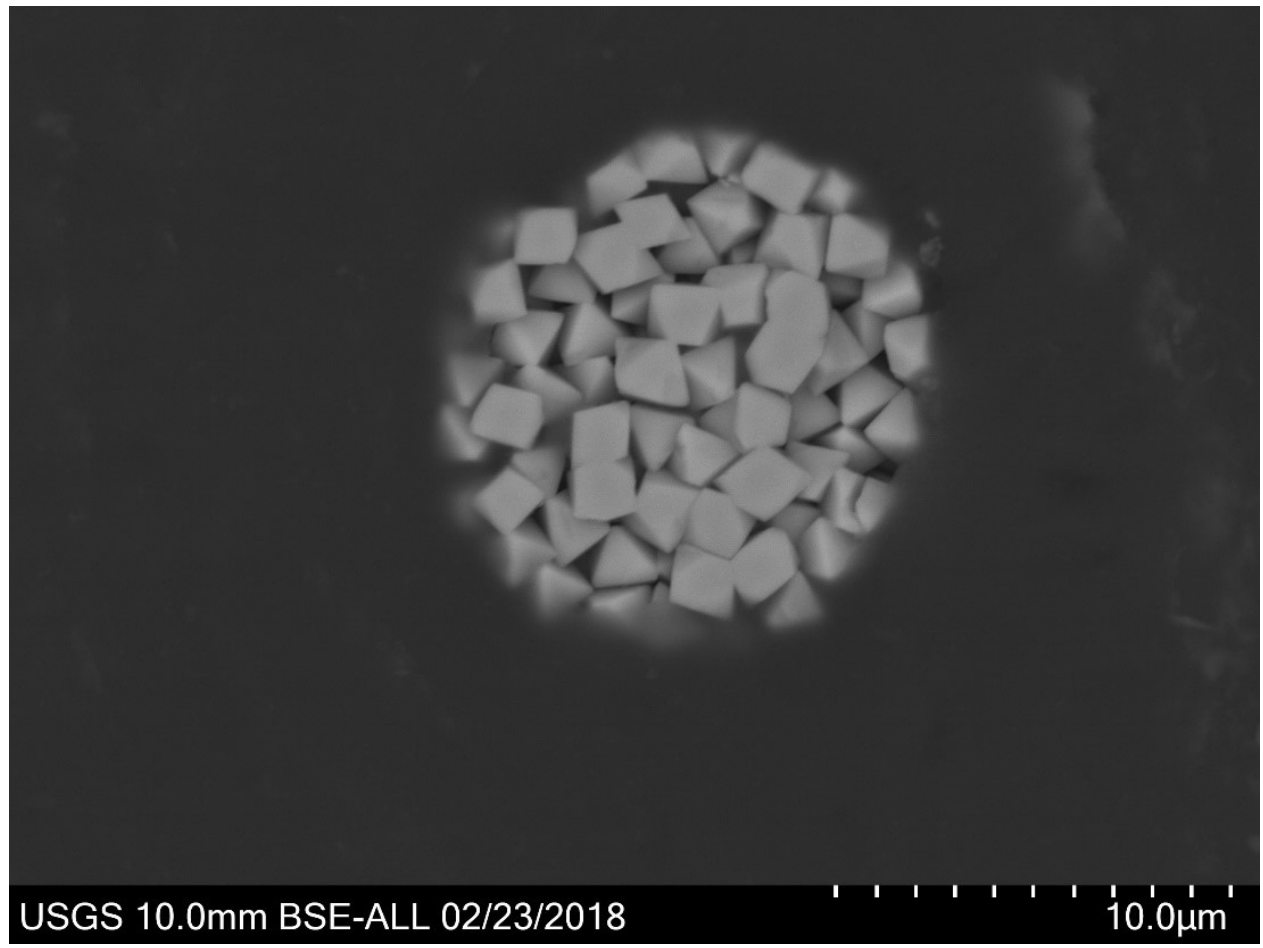

Figure 1.1. Image of a single pyrite framboid. The framboid is composed of an aggregate of approximately $2-\mu \mathrm{m}$ pyrite crystals that exhibit the octahedral crystal structure of pyrite. The $10-\mu \mathrm{m}$-diameter size of the pyrite framboid is typical of Illinois basin coals. Image from sample IL-2, Herrin \#6 coal. Abbreviations: BSE-ALL, backscattered electron-image; IL, Illinois; mm, millimeters; $\mu \mathrm{m}$, micrometers (microns); USGS, U.S. Geological Survey. 


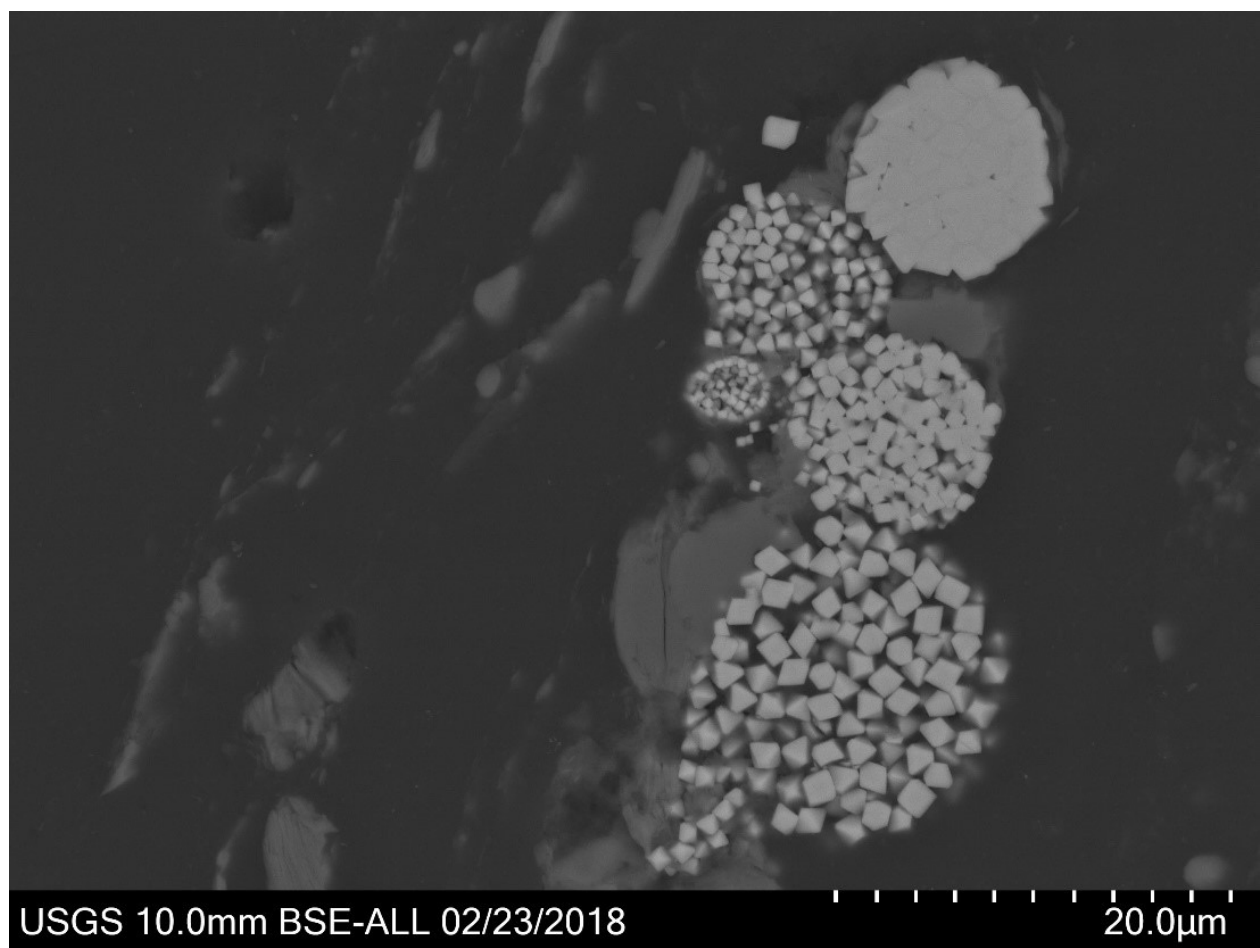

Figure 1.2. Image of a cluster of pyrite framboids from sample IL-2, Herrin \#6 coal. Abbreviations: BSE-ALL, backscattered electron-image; IL, Illinois; mm, millimeters; $\mu \mathrm{m}$, micrometers (microns); USGS, U.S. Geological Survey.

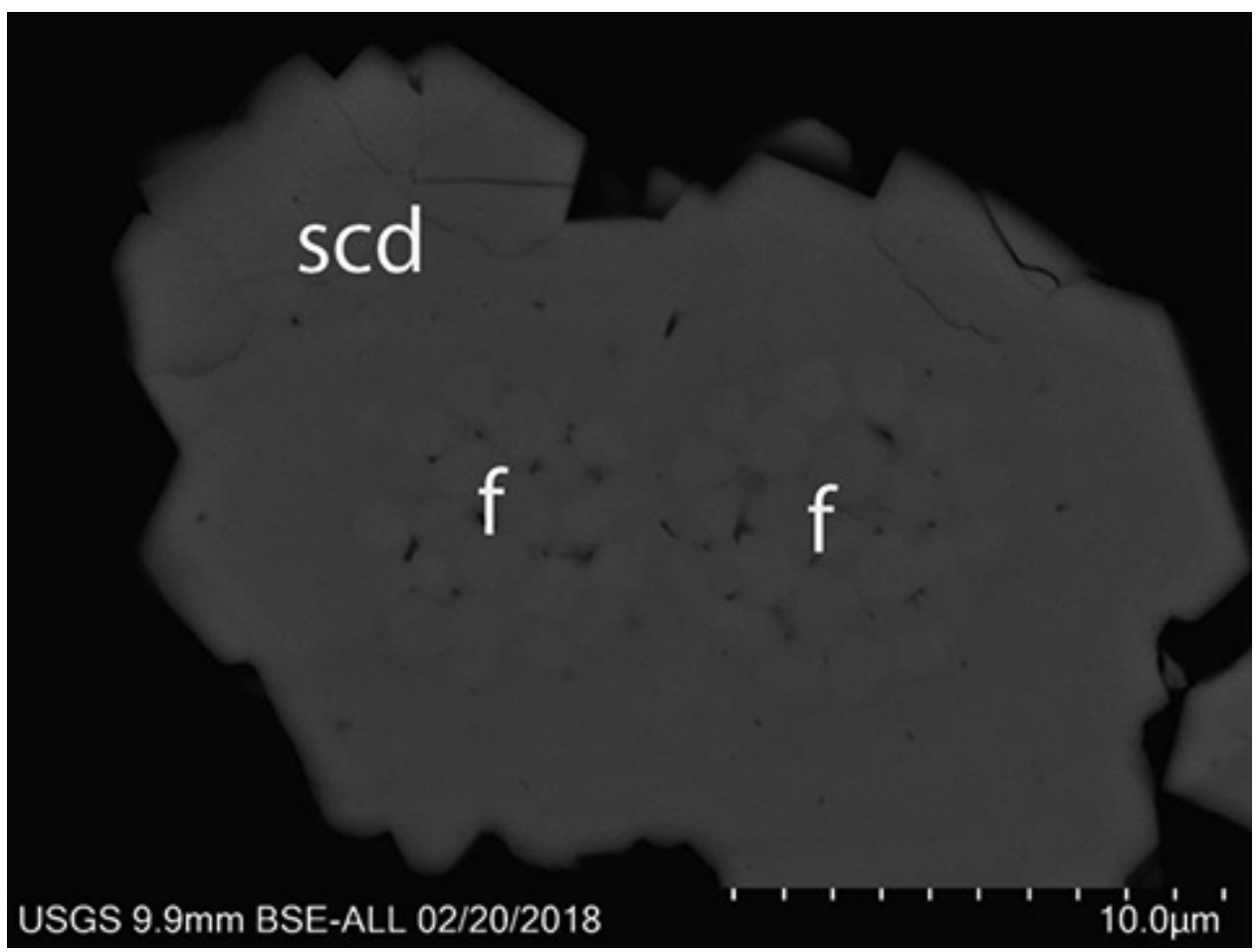

Figure 1.3. Image of two small pyrite framboids (f) that are overgrown by secondary pyrite (scd) from sample IL-1, Herrin \#6 coal. Abbreviations: BSE-ALL, backscattered electron-image; IL, Illinois; mm, millimeters; $\mu \mathrm{m}$, micrometers (microns); USGS, U.S. Geological Survey. 


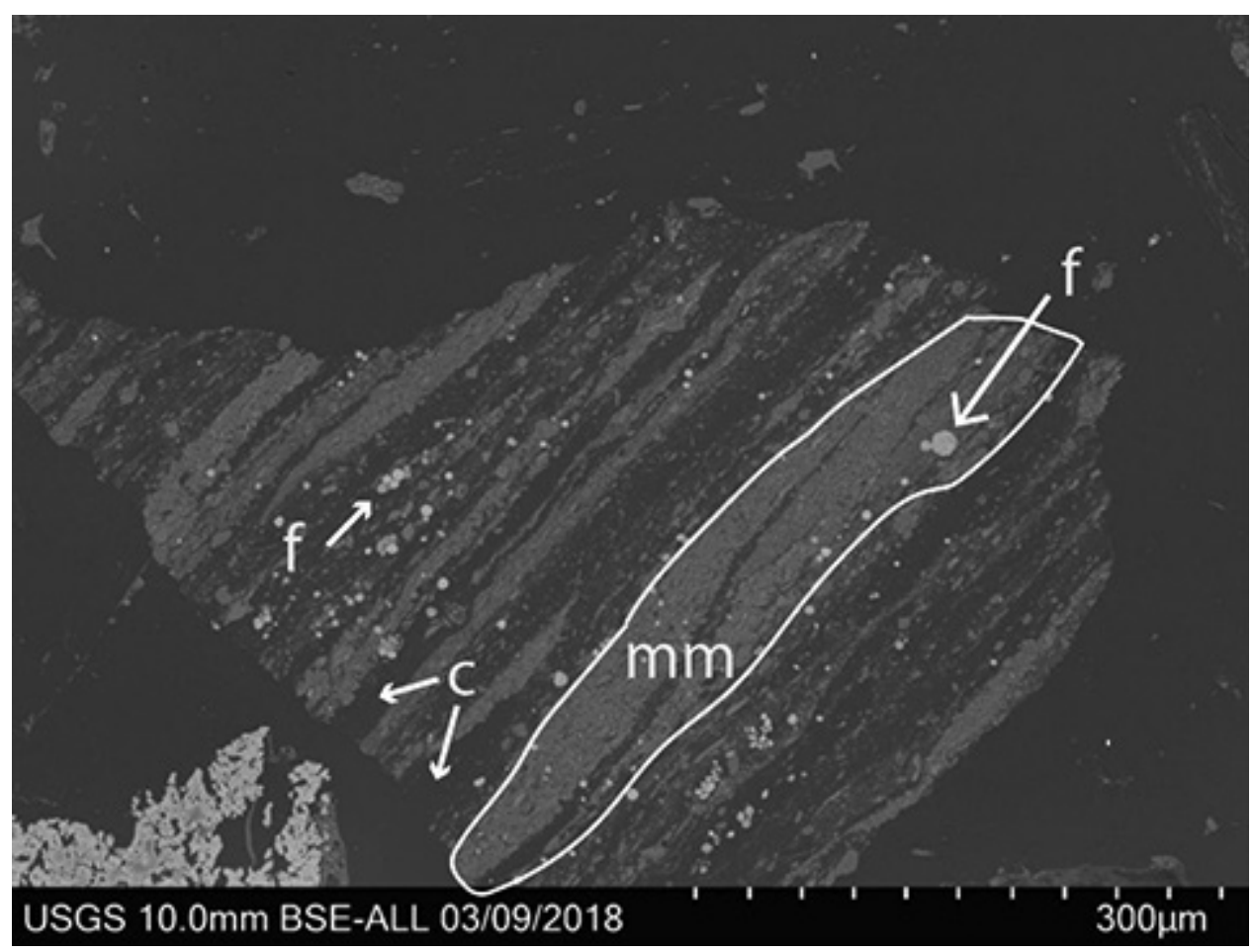

Figure 1.4. Image of a coal fragment hosting pyrite framboids (f) from sample IL-1, Herrin \#6 coal. Dark and gray bands are coal (c) and mineral matter (mm), respectively. Abbreviations: BSE-ALL, backscattered electron-image; IL, Illinois; mm, millimeters; $\mu \mathrm{m}$, micrometers (microns); USGS, U.S. Geological Survey.

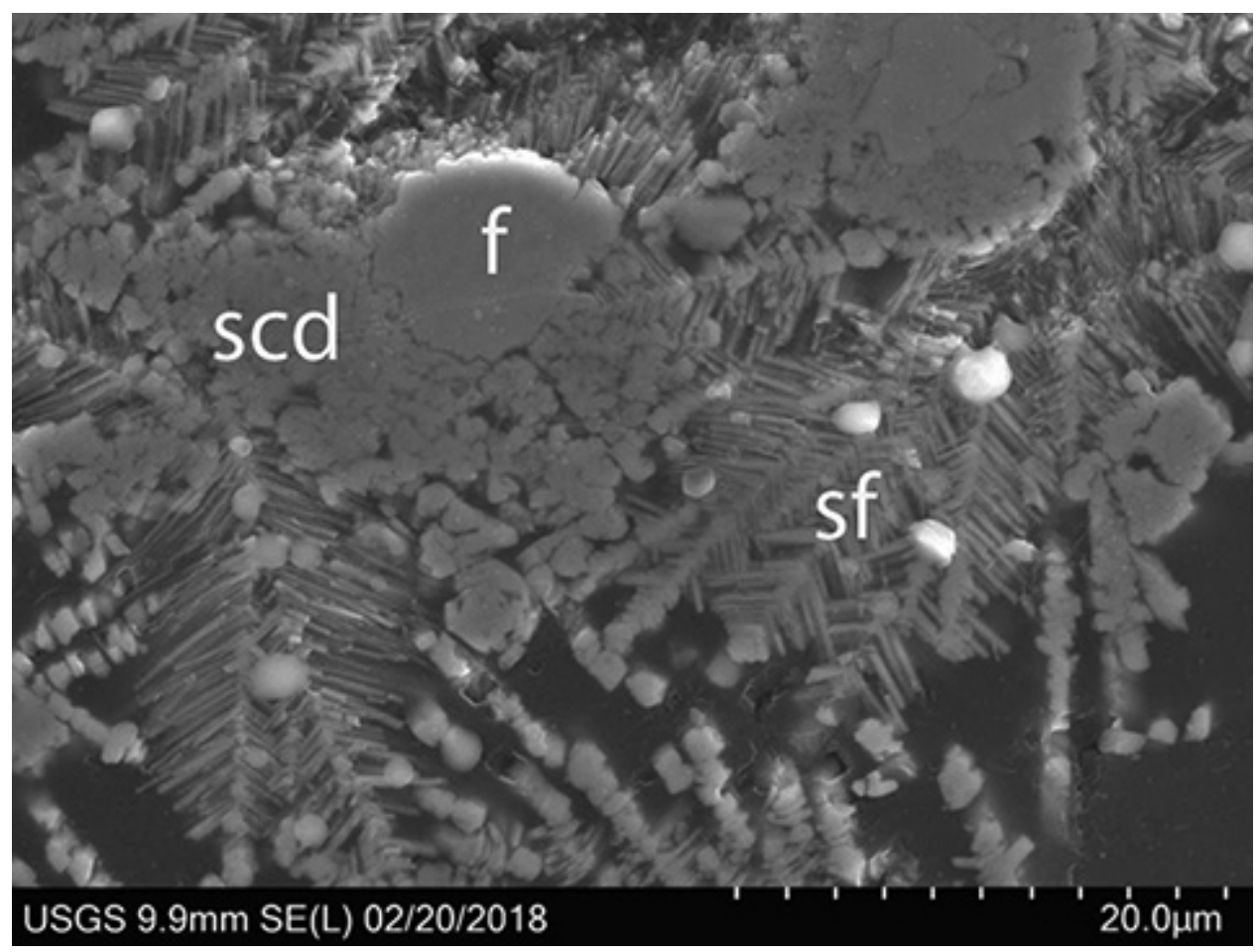

Figure 1.5. Image of a pyrite framboid (f, upper-middle left) surrounded by secondary sulfides (scd) and possible sulfate salts (sf). The image is from sample IL-1, Herrin \#6 coal. Abbreviations: IL, Illinois; $\mathrm{mm}$, millimeters; $\mathrm{SE}(\mathrm{L})$, secondary electron image, $\mu \mathrm{m}$, micrometers (microns); USGS; U.S. Geological Survey. 


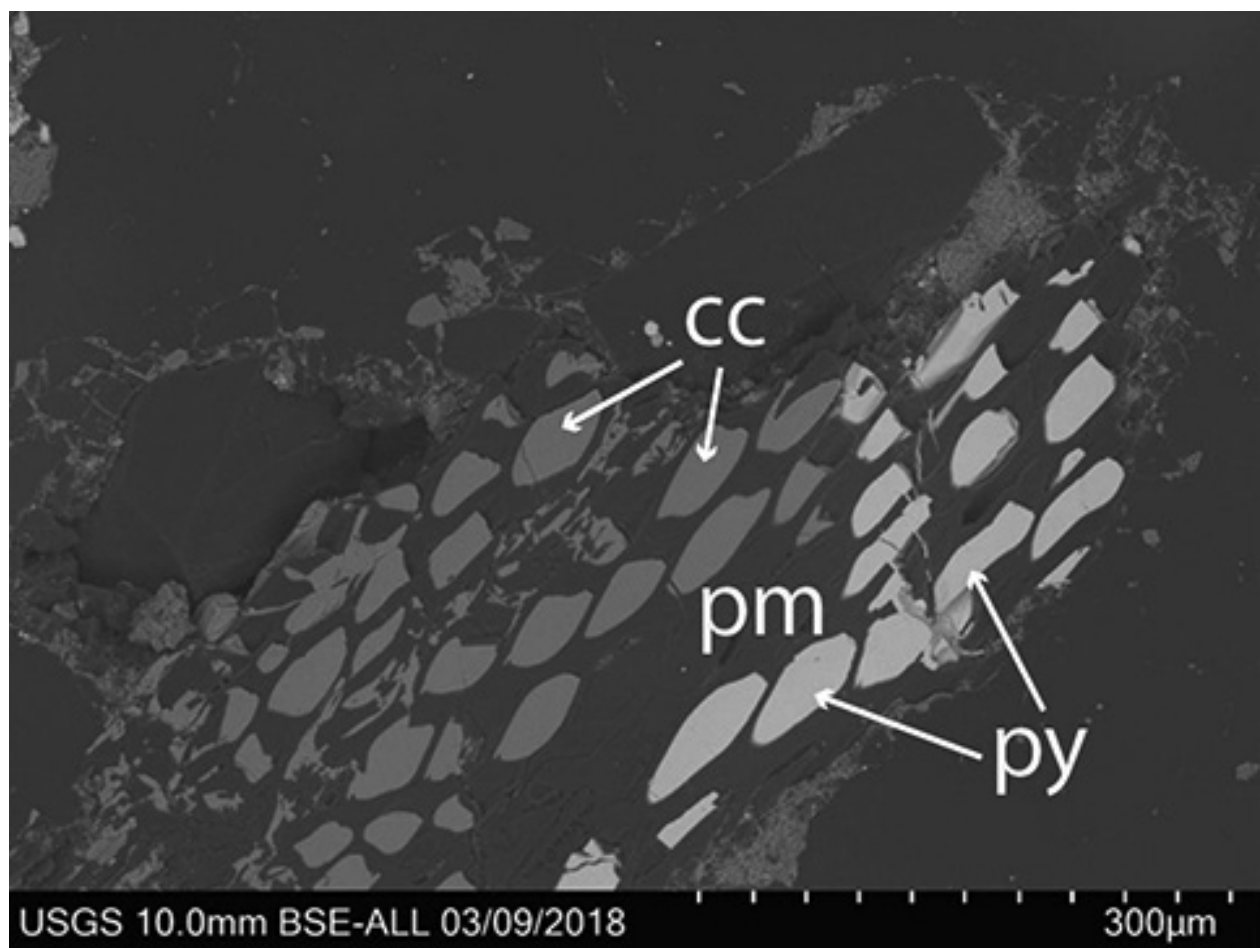

Figure 1.6. Image of plant material (pm) with pyrite (py, high contrast) and calcite (cc, medium contrast) infilling. The image is from sample IL-1, Herrin \#6 coal. Abbreviations: BSE-ALL, backscattered electron-image; IL, Illinois; mm, millimeters; $\mu \mathrm{m}$, micrometers (microns); USGS, U.S. Geological Survey.

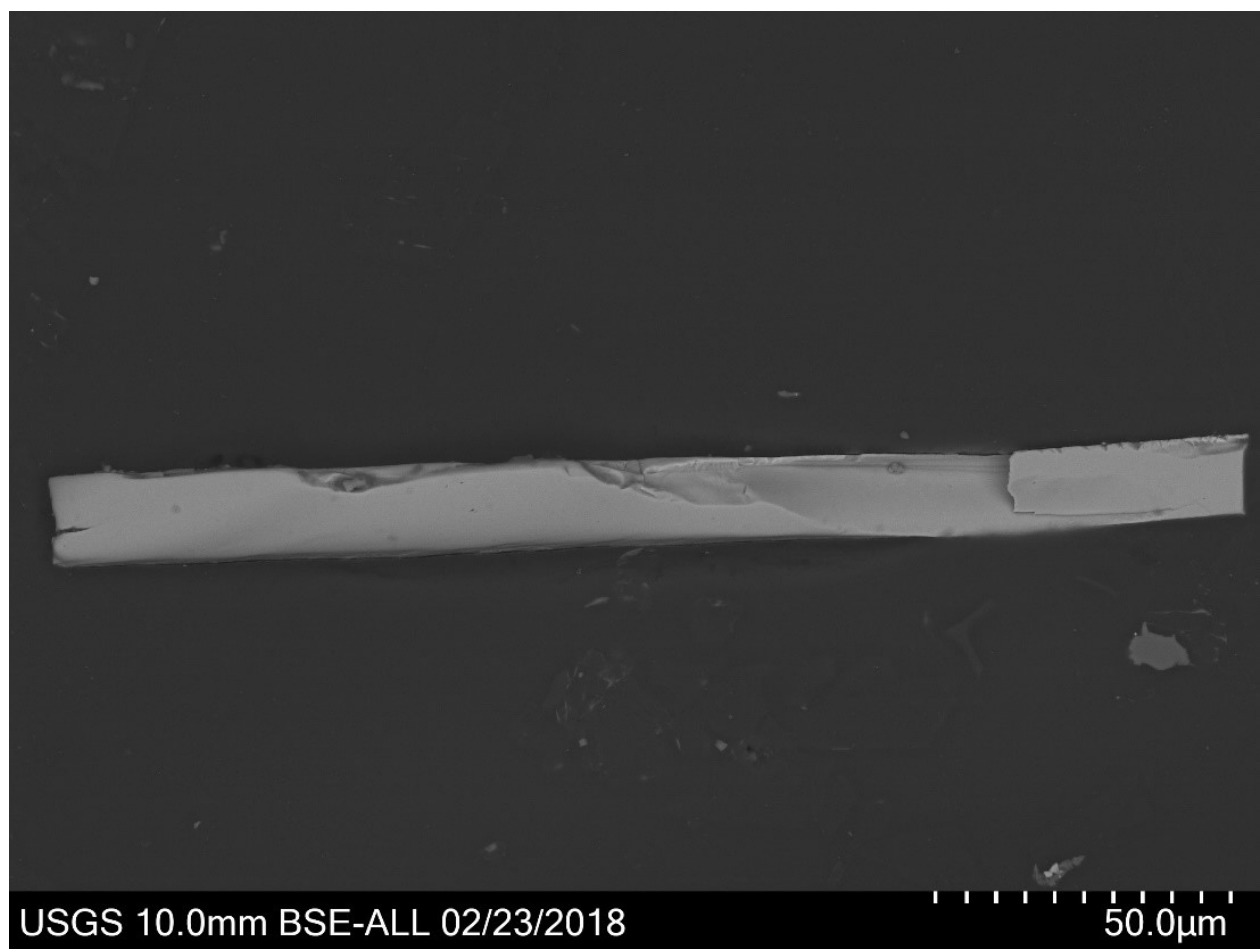

Figure 1.7. Image of a fragment of a secondary pyrite cleat (high contrast) from sample IL-2, Herrin \#6 coal. Abbreviations: BSE-ALL, backscattered electron-image; IL, Illinois; mm, millimeters; $\mu \mathrm{m}$, micrometers (microns); USGS, U.S. Geological Survey. 


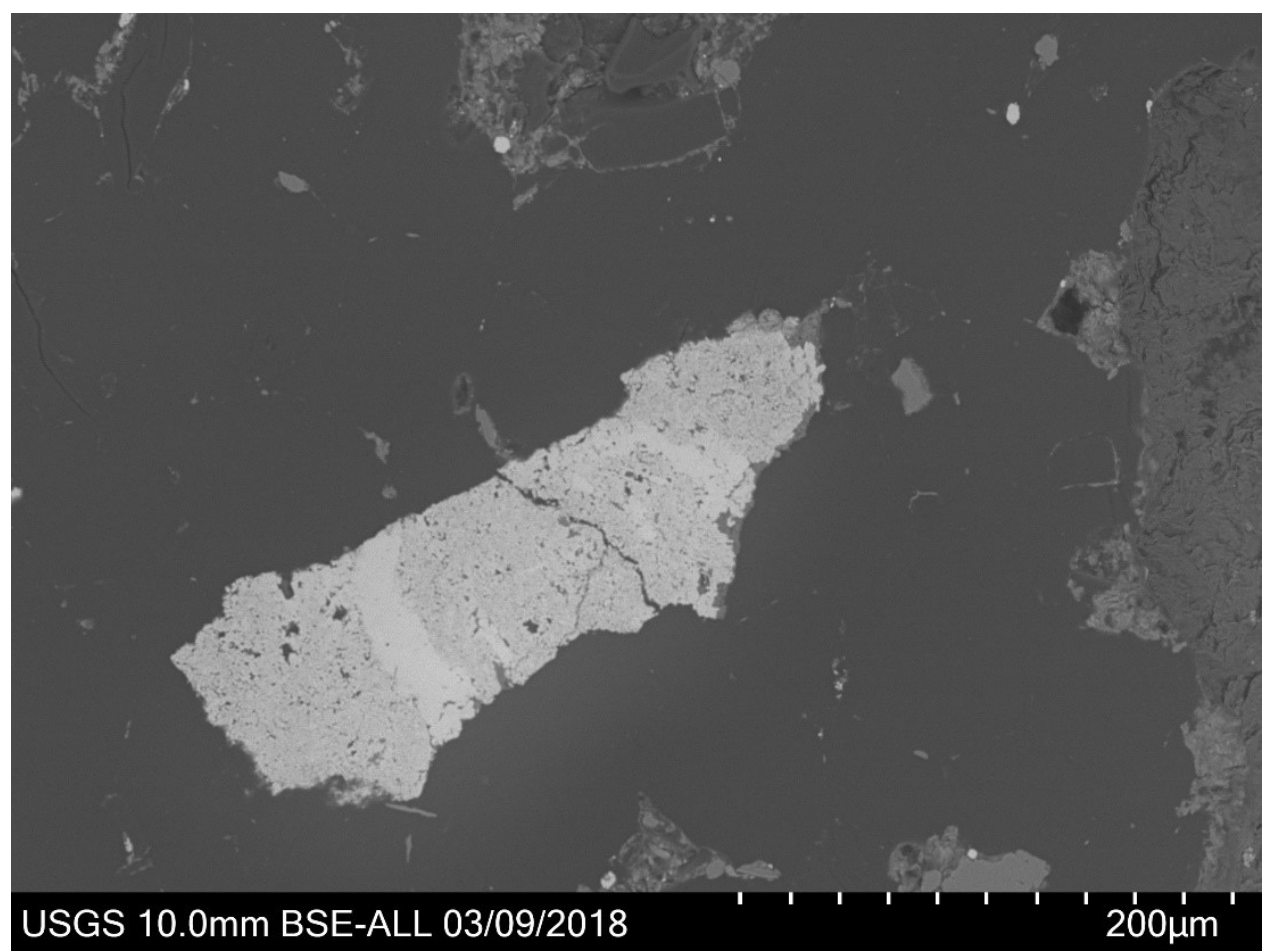

Figure 1.8. Image of a fragment of a secondary pyrite cleat (high contrast) from sample IL-1, Herrin \#6 coal. Abbreviations: BSE-ALL, backscattered electron-image; IL, Illinois; mm, millimeters; $\mu \mathrm{m}$, micrometers (microns); USGS, U.S. Geological Survey.

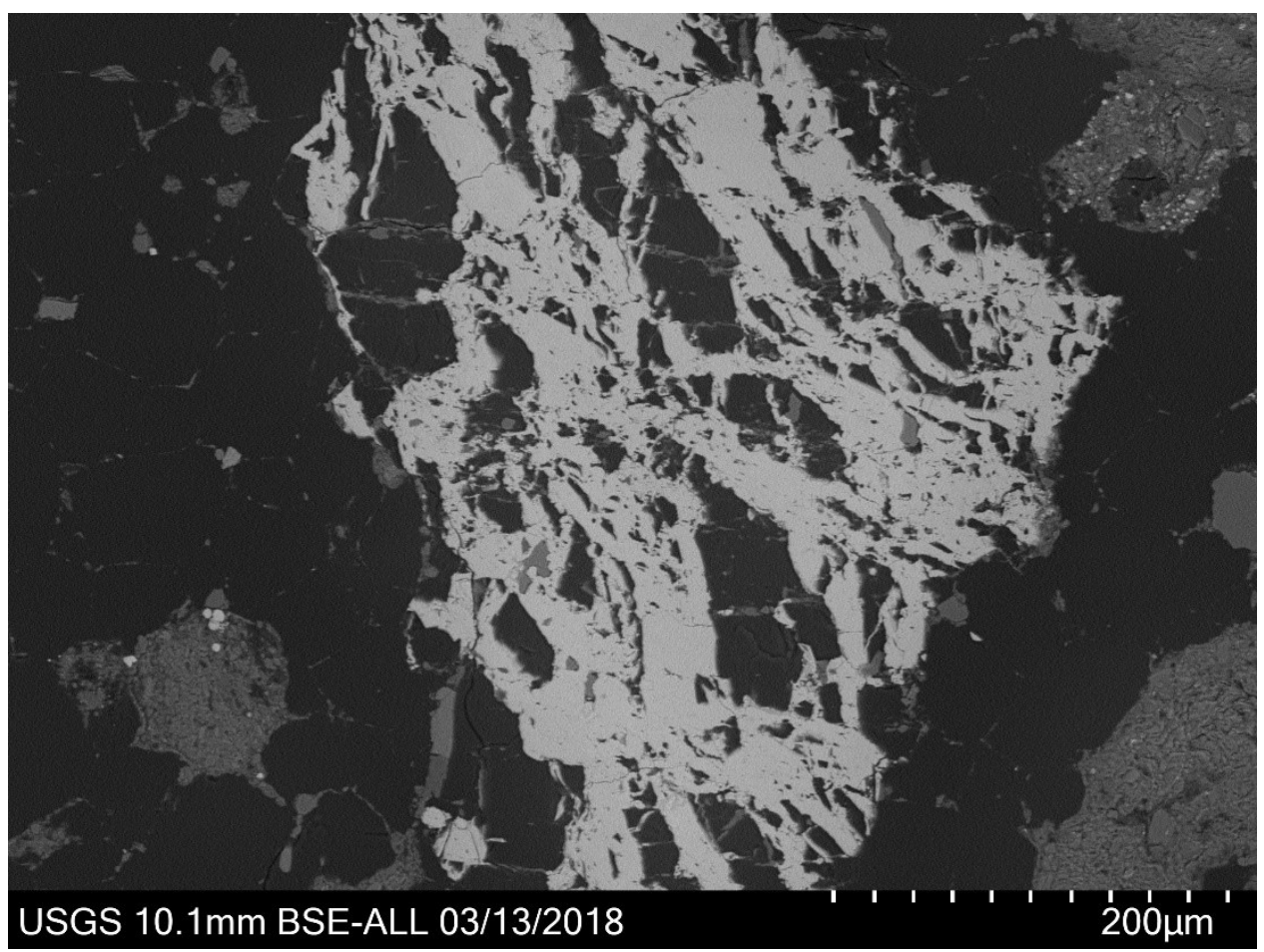

Figure 1.9. Image of a fragment of a secondary pyrite cleat (high contrast) from sample IL-5, Herrin \#6 coal. Abbreviations: BSE-ALL, backscattered electron-image; IL, Illinois; mm, millimeters; $\mu \mathrm{m}$, micrometers (microns); USGS, U.S. Geological Survey. 



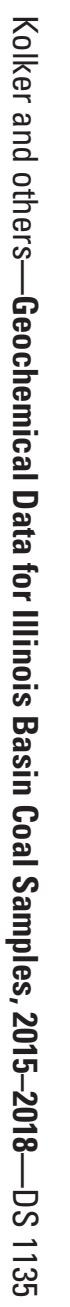

